\title{
Human Resources Development (HRD) and the Universal Basic Education (UBE) in Nigeria
}

\author{
Adokiye A. Okujagu \\ Ignatius Ajuru University of Education \\ Port Harcourt-Nigeria
}

\section{Doi:10.5901/mjss.2013.v4n5p19}

\begin{abstract}
Education, due to its potency, has become recognized as a process by which individuals and society at large can attain their fullest potential. Therefore, education is critical for harnessing human resources to address issues arising from national development and the environment. Laying a solid foundation for education to adequately tap and expand human capital development is of utmost importance if development issues would be addressed using education as an instrument. The level of basic education in developing countries of the world is very low to the effect that it could hinder human resources development. It has, therefore, become imperative to re-examine the basic education scheme and its implementation as a road map to human resources development. Hence, this paper reviews basic education as a tool to develop human resources in Nigeria. In course of the review solutions were proffered and recommendations made to address identified challenges.
\end{abstract}

Keywords: Education, Development, Human Resources Development.

\section{Introduction}

The government of the Federal Republic of Nigeria is resolute in its bid to bring about transformation in all facets of the life of the country. To achieve this, education has been focused on as the ready instrument for this huge assignment. This resolution is in tandem with the declaration that "Education in Nigeria is an instrument "par excellence" for effecting national development (Federal Republic of Nigeria(FRN), 2004: 4). In response to the above, a lot of reforms have been carried out in the education sub-sector in a desperate attempt to improve the quality of education in the country. Launching of the Universal Basic Education (UBE) in September, 1999 and its take-off in 2004 is one of such reforms. The issues that led to the inauguration of the UBE are all developmental in nature. However the extent to which the UBE curriculum implementation is capable of setting the pace in harnessing human potentials for increased human capital development appears to be murky. This is the crux of this presentation. To make for easy digestion; this paper shall be presented under the following sub-sections.

- Concepts of Education and Universal Basic Education (UBE)

- $\quad$ Aims/purposes of education and UBE

- Human Resources Development (HRD)

- Issues in Human Resources Development via Universal Basic Education In Nigeria

- Solutions and Recommendations.

\section{Concepts of Education and Universal Basic Education (UBE) Education}

There exists a wide range of definitions and meanings of the concept "Education" Generally speaking, 
education is the means through which the aims and habits of a people are transmitted from one generation to another. In its technical usage, education is the formal process by which society deliberately transmits its accumulated knowledge, skills, customs and values from one generation to another (Wikipedia, 2011) According to Collin English Dictionary (2009), education is the process of imparting or acquiring general knowledge, developing the powers of reasoning and judgement, and generally of preparing oneself or others intellectually for mature life.

From the professional perspective, Aigbomian and lyamu (2001) defined education as an orderly and deliberate effort to transmit or develop knowledge, concepts, skills, attitudes, values and habits. It is the process of socialization by means of which an individual is taught what is desirable in the society. Education may be defined as a co-operative, dynamic, and life long process through which a society deliberately generates knowledge, skills values and other forms of behaviour for its survival and sustenance and transmits same from one generation to another (Edozie, 2003). There are matters arising from the above discourse on the definition and meaning of education and these include the following:

- Education deals with the generation, transmission and acquisition of knowledge, skills, values, attitudes and habits, among others.

- It has to do with the all-round development of an individual.

- Education is, and must, be rooted in the culture of the people

- Education is handed down from one generation to another

- It is a life long process

- An agency is assigned the responsibility of education

- Education prepares one to be useful to both himself and society at large.

\section{Universal Basic Education (UBE)}

Federal Ministry of Education, FMOE, (2009) defines basic education as "the education offered to children aged between 3 and 14 years. It comprises 3 years of Early Childhood Care Development and Education (ECCDE), 6 years of primary and 3 years of Junior Secondary Education. It also covers special interventions directed at nomadic and migrant children mass literacy as well as the almajiris and other vulnerable and excluded groups p5.".

Federal Republic of Nigeria, FRN, (2004) asserts that

"Basic education shall be of 9-year duration comprising 6 years of primary education and 3 years of Junior Secondary education. It shall be free and compulsory. It shall also include adult and non-formal education programmes at primary and Junior Secondary education levels for the adult and out-of-school youths, $p$ 13"

The above definitions reveal the fact that UBE is a policy reform measure by the government of the Federal Republic of Nigeria aimed at reforming the basic education sector in the country. The scheme is structured towards the eradication of illiteracy, ignorance and poverty as well as to stimulate and accelerate national development in the country.

Education, UBE inclusive, in this paper aims at the generation, acquisition and transmission of knowledge, skills, values, attitudes and habits in a formal institution for the well being of the individual and society at large. This makes education the central pivot of human resources development.

\section{Aims and Purpose of Education and Universal Basic Education (UBE)}

As an instrument in meeting the hopes, values, demands, yearnings, aspirations and challenges of a people and solving their pressing problems, education can differ from country to country. In Nigeria, for example, the goals of education are as follows: 
a. "the inculcation of national consciousness and National Unity;

b. The inculcation of the right type of values and attitudes for the survival of the individual and the Nigerian Society;

c. The training of the mind in the understanding of the world around; and

d. The acquisition of appropriate skills and the development of mental, physical and social abilities and competencies as equipment for the individual to live in and contribute to the development of the society" (FRN, 2004:8).

In order to achieve the above stated national goals of education, the quality of instruction at of all levels must be directed towards inculcating the following values.

a) "respect of the worth and dignity of the individual;

b) faith in man's ability to make rational decisions;

c) moral and spiritual principle in interpersonal and human relations;

d) shared responsibility for the common good of society;

e) promotion of the physical, emotional and psychological development of all children; and

f) acquisition of competencies necessary for self reliance" (FRN, 2004:8).

On a general note, the UBE is an educational programme aimed at the eradication of illiteracy, ignorance and poverty as well as to stimulate and accelerate national development and political consciousness among Nigeria. The specific objectives of UBE are as follows:

a) "Developing in the entire citizenry a strong commitment for education and strong commitment for its vigorous promotion.

b) The provision of free, universal basic education for every Nigerian child of school-going age.

c) Reducing drastically the incidence of dropout from the formal school system through improved relevance, quality and efficiency.

d) Catering for the learning needs of young persons who, for one reason or another, have to interrupt forms of complementary approaches to provision and promotion of basic education.

e) Ensuring the acquisition of appropriate levels of literacy, numeracy, manipulative, communication and life skills, as well as the ethical, moral and civil values needed for laying a solid foundation for life-long learning" (UBE, 2004: 5-6).

\section{Purpose of Education.}

As children, we were once told, and we are still telling our children that education is the key to unlock the door to success. This is against the back drop of the fact that for development to take place, education is often listed as one of the components to achieve it. Some other components of development also depend on education to initiate development.

A critical analysis of the goals of education and objectives of the UBE reveals that the purpose of education is personal, social and ever-changing. Education prepares individuals for effective citizenship, helps students become critical and independent thinkers and enhances students' ability to compete in a global marketplace as well as preparing students for specific career. At the social level, education engenders the inculcation of national consciousness and national unity, and enhances the acquisition of appropriate skills and the development of abilities and competencies as equipment for the individual to live in and contribute to the development of the community. Education is also responding to the dynamic nature of society.

Colonial education which primarily dealt with the development of the cognitive domain to the detriment of the affective and psychomotor skills has now been overtaken by the 6-3-3-4 system which places emphasis on acquisition of technical and vocational skills. Right now, the emphasis has shifted to entrepreneurial education for job creation and empowerment. 
In order to reposition individuals and the nation in this era of global competitiveness, Information Communication Technology (ICT) education has also been integrated in the curriculum for schools.

\section{Human Resources Development (HRD)}

In order to comprehend the concept "Human Resources Development", it is pertinent to properly identify the concept of human resources. Human resources is the manpower or workforce required by a nation or organization to enable it achieve its predetermined objectives or to serve the purpose for which it is established. Human resources of a nation would, therefore, refer to the totality of population of a country, which determines the potent labour force of a nation,. Investment in the human resources determines the availability, quality and type of manpower in that nation (European Commission, 2007). The revelation inherent in the above is that the human beings who inhabit a nation are its greatest assets. Thus, conscious effort should be made at any point in time to build the capacities of these individuals so that the purpose of building a virile nation would be achieved. This is human capital development in action.

Human Resources Development (HRD) can be described as the framework for helping individuals develop their personal and organizational skills, knowledge and abilities. The primary focus of HRD is on developing the most superior workforce to enable individuals, nations and organizations accomplish their work goals to the citizens and clients. HRD includes such opportunities as training, career development, coaching, mentoring, among others. Formal and informal forms of HRD exist. A formal HRD can be found in the case of classroom training or an organizational planned/deliberate change effort, and informal such as in an employee being coached by a manager.

The development of a nation depends heavily on the development and capabilities of human being (manpower) residual in that nation. This is the reason why man is viewed as the most important asset in the process of human resources development (Drucker, 1999).

Developed countries of the world such as the United States of America, Britain, Germany, Japan, Russia, China to mention a few have planned manpower development in a way which ensures that the right kind of people are at the right place and at the right time, and who are doing things for which they are economically most useful (Gyang, 2011). This is often achieved through education and training. Miachi (2006) observed a high correlation between economic growth of these advanced economies and the quantum and kinds of education provided to their workforce.

In summary, HRD, which is also referred to as manpower development in some literature, is a continuous process of injecting new viable ideas, knowledge, skills, attitudes and values into citizens as may be dictated by the requirement of development strategies of a nation. It is a means of keeping individuals abreast of current information about high productivity through education and training. This means that HRD is a framework for human capital expansion aimed at increase in productivity via performance improvement, and Adam Smith in Kelly (2001) notes that the capacities of individuals depended on their access to education.

\section{Issues in Human Resources Development (HRD) via Universal Basic Education (UBE) in Nigeria.}

Universal Basic Education in Nigeria is a deliberate effort to keep faith with the attainment of Education for ALL (EFA) and the Millennium Development Goals (MDGs) by 2015. To make Nigerians responsive to the goals of EFA and MDGs, implementation of the National Economic and Empowerment Development Strategies (NEEDS) is being vigorously pursued. NEEDS can be summarized as value-reorientation, poverty eradication, job creation, wealth generation and using education to empower the people (Obioma, 2007). To realize these, it became imperative that circula be packed for implementation in all the segments of basic education: lower basic (primary 1-3), middle basic (primary 4-6) and upper basic (JSS 1-3) (Federal Ministry of Education( FMOE), 2006). 
As a nation that believes in using education as a tool for human capital expansion, Nigeria introduced technical and vocational education, and other emerging issues such as value re-orientation, peace and dialogue, human rights education, entrepreneurial skills, family life and HIVIAIDS education into the basic education sector. All these are aimed at laying a solid foundation for developing human resources. However, the worrisome issue is the general poor quality of the products of the education sector which might be a huge challenge to human resources development in Nigeria.

These challenges which are not particularly inherent in the system of education have been compounded by other factors, which are likely to impede effective implementation of the 9 year basic education scheme. The factors include:

\section{Educational Infrastructure}

This encompasses all physical facilities needed to make schools function as intended and attain set goals. These include classroom and office blocks, laboratories, furniture, equipment and materials, toilet and water facilities. A dearth of these basic school facilities in the basic education sector does not promote a congenial environment for teaching and learning to thrive. Basic education level of education is the introductory stage for acquisition of all types of productive skills at the disposal of the learner, but when the facilities for such purpose are grossly inadequate, it impacts negatively on human resources development. This is in the sense that experiences which will lead to unveiling and harnessing human potential and talents are inhibited due to inadequate educational infrastructure.

In addition, it has even become more problematic to maintain existing infrastructural facilities in basic schools. This is evident as learners in most basic schools across the country are seen learning in dilapidated and roofless buildings or even under trees, sitting on broken chairs and desks or even on bare floor, and carrying out practical work in open halls without the necessary equipment and materials.

These conditions defeat learners psychologically and dampen their interests in the process of developing their talents and potential. Okujagu and Adox-Okujagu (2011) noted that there is an urgent need to provide these facilities in terms of adequacy, appropriateness and gender sensitivity because their use maximizes the benefits from educational programmes.

\section{Professionally Qualified Teachers}

It is often said that no school system can rise above the quality of its teachers. To this effect, FRN (2004) enunciates that all teachers in educational institutions shall be professionally trained. Thus, teacher education programmes shall be structured to equip teachers for the effective performance of their duties. However, it is worrisome to note that many teachers in both private and public basic education schools are graduates in courses other than education. The high rate of unemployment in the country has further compounded this situation. Another worry expressed by FMOE, (2009) is the alarming discrepancy between teacher certified competence and performance on the job. To address these issues, Government of the Federal Republic of Nigeria through the instrumentality of Universal Basic Education Commission (UBEC) and State Universal Basic Education Boards (SUBEBs), has from time to time embarked on some capacity building exercises for teachers in the basic education sector.

However, it appears to all and sundry that these programmes have never been evaluated, monitored and followed up to ascertain or determine the effectiveness and utility of the newly acquired techniques and skills by teachers during instructional delivery.

Since naturally, one can only reap what he sows, the above scenario is not in favour of human capital development. This is in the sense that competence and performance on the job of most teachers in the basic education sector is unsatisfactory. Therefore, human resources development talents and potential of basic education graduates are likely to be impaired. 


\section{Information Communication Technology (ICT)}

As with other levels of education, ICT has been introduced into the basic education programme. This is in recognition of its prominent position and role in advancing knowledge and skills required for effectively functioning in a global village occasioned by modernity in science and technology. The use of ICT has proved very rewarding in teaching and learning, agriculture, health, governance, trade, budgeting and industries to mention a few, hence it was integrated into the curriculum. However, the matters arising from this integration have been very overwhelming. The computer is one primary device for ICT compliance, but unfortunately, majority of teachers who are to teach computer education to students in the basic education programme are themselves illiterates in the field. How can a blind lead the blind?. There is also a dearth or paucity of ICT gadgets, materials and equipment in the basic schools, especially the public ones. Since ICT relies on electricity, its functionality maybe hampered due to the epileptic nature of power supply in schools where they may be found.

\section{Instructional Materials}

Materials/resources for instruction are very critical to the teaching and learning process. Instructional materials which are alternative channels of communication concretize learning and give life to concepts being learnt. Besides, instructional materials give direction as to the achievement of set school goals. This is true of curricula documents such as National Policy on Education, National Policy on Integrated Early Childhood Care and Education, National Minimum Standards, Curriculum for Early Childhood Education and the 9 year UBE curriculum. These documents are the pivot of the entire basic education system, but it is disheartening to observe that they are hardly found in teachers' possession. The author's visits to various basic schools in Rivers state for clinical experience (teaching practice supervision) revealed that even the recently launched 9 year UBE curriculum is yet to reach many schools. The question here is "What directs teaching and learning in these schools?" The use of these curricula documents cannot be over emphasized as they enunciate curricula goals for achievement and suggest activities (i.e. teaching-learning activities) and materials/resources to attain such goals. The fact that these documents are yet to reach a good number of basic education schools, teachers continue to equip students with obsolete knowledge, skills and habits that may not be in tandem with the principles of human resources development in a modern world.

\section{Fund:}

The success of the Universal Basic Education hinges on adequate funding. Provision of educational infrastructure, training of professionally qualified teachers, procurement and maintenance of ICT resources, and production and distribution of instructional materials/resources are all capital intensive ventures, and so require huge amount of money to embark upon them. To add to this financial burden is the declaration by the Act that established the UBE. The Act asserts that UBE is free, compulsory and universal. Thus, the UBE project is a huge enterprise that ought to take a substantial chunk of the nation's budget, if it has to be well implemented (Osokoya, 2011).

\section{The Way Forward}

The population of Nigeria has increased to about 150 million people, and there are clear indications that it will continue to rise owing to disease preventive strategies, improved healthcare services and modern science and technology. This implies that the population of school aged children will also rise. In this direction concerted efforts should be made by government, corporate bodies, especially the multi-national corporations, Non Governmental Organizations (NGOs) and well-meaning individuals to set up the quantum 
of infrastructure required in the UBE sector. This is to ensure that students learn in a congenial and attractive environment where their respective potential and talents can be identified and harnessed.

Greater effort should be made in ensuring that teachers in the UBE scheme are trained to qualify for the job. This is against the background of the fact that many teachers at this level do not have background/qualification in education. The capacity of teachers on the job should be built regularly to expose them to modern skills and methodologies in teaching. Such capacity building exercises should also be evaluated and monitored to ensure consistency with set educational goals.

Due to the importance of ICT, its procurement and maintenance should not be left for government alone. Parents, NGOSs, corporate organizations and philanthropists should assist in the procurement and maintenance of ICT resources. Computer literacy should also be made a condition for appointment and promotion of teachers in the basic education system. This will facilitate teaching of computer education.

Instruction materials should as a matter of priority be made sufficiently available in basic education schools. Besides concretizing teaching and learning they also have the capacity of bringing about quality and standards in instruction. Curricula documents such as the curriculum/syllabus, policies, minimum standard etc. should be made available to all basic education schools, especially those in the rural and remote areas, for these are the places Nigeria has more of its school aged children.

Funds are very critical to the execution of a venture that is as huge as the UBE project. In addition to governments subscription to basic education, the establishment of an educational development bank should be given serious thought or consideration. This bank will be responsible for receiving monies from government and its agencies, corporate bodies, Nigerians in the diaspora and at home, and other world bodies, and then disburse same for educational developments.

\section{Conclusion}

A conscious applications of the recommendations so far made will fast track human resources development at the basic level of education in Nigeria.

\section{References}

Aigbomain, D. O. \& lyamu, E. O. S. (2001). Foundations of Curriculum Studies. Lagos: Metro publishers Ltd.

Collins English Dictionary - Complete and Unabridged (10 th ed.) (2009). Harper Collins Publishers.

Drucker, P. F. (1999). Management Challenges for the 21st century. New York: Harper Business.

Edozie, G. C. (2003) Curriculum Resources and Educational Technology. Asaba: View Point publishing Company.

European Commission (2007). Enterprise and Industry Directorate -General. Europe: Brussel, Europe.

Federal Republic of Nigeria, FRN, (2004). National Policy on Education (4th Ed.). Abuja: Nigerian Educational Research and Development Council (NERDC).

Federal Ministry of Education, FMOE, (2006). 9-YEAR Basic Education Curriculum. Abuja: Nigerian Educational Research and Development Council (NERDC).

Federal Ministry of Education, FMOE (2009) Roadmap for Nigerian Education Sector. Abuja: FMOE

Gyang, T. S. (2011). Human Resources development in Nigeria: The roadmap for vision 20:2020. International Journal of Economic development, research and investment 2(1), 70-79.

Kelly, D. (2001). Dual perception of HRD: Issues for Policy: SME's other constituencies, and the contested definitions of Human Resource Development. http//ro.uow.edu au/art papers/26. retrieved September, 2010.

Miachi, T. A. (2006). A systemic Approach to human resources development and utilization: A sectoral analysis. A lead discussion of the interactive session with the senior executive course No. 28 of the National Institute for Policy and strategic studies (NIPSS) Kuru, Jos.

Obioma, G. (2007). Attaining the Millenium Development Goals (MDGS); Nigeria's Experience in Education reforms. Keynote address presented to the national conference of the faculty of Education, University of Nigeria, Nsukka. August $6^{\text {th }}-9^{\text {th }}$. 
Okoro, I. F. (2010). Challenges in Effective Curriculum Implementation at Primary Education Level in Nigeria. In Iloputaife E. C. Maduewesi, B. U. \& Igbo, R. O. (Eds), Issue and Challenges in Nigerian Education in the $21^{\text {st }}$ Century (pp 257-280). Onitsha: West and Solomon Corporate ideals Ltd.

Okujagu, A. \& Adox-Okujagu, H. S. (2011). A three point agenda/antidote to the challenges of the implementation of the Universal Basic Education (UBE). A paper presented at the $13^{\text {th }}$ Annual Conference of NAFAK March $14^{\text {th }}-18$, Uyo.

Osokoya, I. O. (2011). 6-3-3-4 Education in Nigeria: history, Strategies, Issues and Problems. Ibadan: Laurel Educational Publishers.

Wikipedia (2011) Education.Retrieved from http//en.wikipedia.org/w/index.php?title=Education\& oldid=507885731. 